623.4 .016

. . упріненко ${ }^{1}$, . . олуб ${ }^{2}$

1 ввівський інститут ухопутних військ, ввів

2 ентр льний н уково-дослідний інститут озброєння $m$ військової техніки бройних ил кр їни, иїв

роведено н ліз існуючих н уково-методичних підходів щодо обгрунтув ння $m$ ктико -технічних вимог до перспективних зр зків озброєння $m$ військової техніки. ст новлено, що в суч сних умов хн поч ткових ет $n$ х розробки вони не дозволяють дост тньо вр хув ти невизн ченість вихідних д них $i$ неоднозн чність опису процесу використ ння перспективних зр зків озброєння $m$ військової техніки.

пропонов но підхід, який грунтується н використ нні поняття нечіткої множини $m$ дозволяе обгрунтув ти т ктико-технічні вимоги до перспективних зр зків озброєння $m$ військової техніки в суч сних умов х.

лючові слов : $m$ ктико-технічні вимоги, озброєння $m$ військов технік, нечітк м ножин .

\section{сту П}

ост новк проблеми. спіх будь-якого технічного проекту зн чною мірою $з$ лежить від мистецтв формув ння технічних вимог і вибору р ціон льного шляху його ре ліз ції.

ехнічні х р ктеристики виробу, які визн ч ють його технічний обрис, $з$ кл д ються в результ ті проведення н уково-дослідних робіт н поч ткових ет п х розробки. ри цьому м ють місце т кі х р ктерні особливості, як невизн ченість бо недост тня кількість вихідної інформ ції, т кож висок цін помилок рішень, що прийм ються.

езульт ти досліджень, отрим ні мерик н ськими ф хівцями в ході н лізу діяльності 500 комп ній т понії, пок з ли, що мерик нські т японські фірми витр ч ють н поч тковому ет пі розробки від 25 до $40 \%$ фін нсових коштів, які виділені н той чи інши й проект [1].

остійний розвиток форм і способів ведення збройної боротьби, обумовлений дин мічністю т нест більністю подій і процесів, що відбув ються в суч сних умов х, вим г $€$ перегляду т ктико технічних вимог ( ) до перспективних зр зків озброєння т військової техніки ( ).

н ліз ост нніх досліджень і публік цій. очин ючи 3 другої половини століття для обгрунтув ння до перспективних зр зків 3 стосовують різні м тем тичні п р ти. робот $\mathrm{x}$ [2-4] використовуються методи дослідження опер цій. ля подол ння ф кторів невизн ченості в 3 зн чених робот $\mathrm{x}$ вводяться припущення при визн ченні вихідних д них. прикл д, при виборі к лібру ртилерійського сн ряд [2] прийм ються (C) . . упріненко, . . олуб чіткими зн чення площі зони ур ження, м ксим льн д льність стрільби. ле н д ння чітких гр ниць «вольовим» порядком чи штучне введення однозн чності озн ч є не що інше, як огрублення вихідних д них, т може сприяти отрим нню хоч i чіткого, ле не вірного результ ту [5].

стосув ння ймовірнісно-ст тистичних методів, які використовуються, н прикл д, в робот х [6-7], в суч сних умов х обмежено т кими обст вин ми:

1. еобхідністю вр хув ння ф кторів невиз н ченості, які м ють нест тичну природу. той же ч с основним припущенням при ст тистичному прогнозув нні є припущення про незмінність х р ктеру впливу різних ф кторів н величину, що досліджується, як у минулому т теперішньому, т к і в м йбутньому.

2. едост тньою кількістю бо неможливістю отрим ння достовірних ймовірнісно-ст тистичних д них при проектув нні скл дних зр зків (комплексів) (особливо у тих вип дк х, коли створюються зр зки Н нових фізичних принцип х), необхідністю вр хув ння великого обсягу різном нітної т суперечливої інформ ції (в тому числі й якісної), що призводить до в жкопереборних м тем тичних скл дностей при ї̈ форм ліз ції.

оряд 3 об'єктивністю ст тистичних методів прогнозув ння вони т кож не виключ ють можливості виникнення грубих помилок, особливо у сфері стрибкоподібних змін величини, що прогнозується. лід з ув жити, що умови отрим ння з конів розподілу ст тистичних д них у суч сних умов $\mathrm{x}$ х $\mathrm{p}$ ктеризуються низкою методичних, обчислюв льних т інформ ційних 
скл дностей [7], н с мперед, у визн ченні структури моделей, суттєві обмеження н проведення н турних випробув нь, неможливість прям ого вимірюв ння низки п р метрів, нерідко великі втр ти ч су т інших ресурсів для отрим ння необхідної інформ ції. іпотетичний вибір цього 3 кону не виключ $є$ можливості спотворення необхідних т ктико-технічних х р ктеристик перспективних зр зків

роботі [8] обгрунтув ння здійснюється

н підст ві порівняльного н лізу існуючих зр зків

із використ нням принципу іде льного зр зк . орівняльний н ліз проводиться з використ нням модифіков ного методу н лізу ієр рхій 3 критерієм м ксимуму уз г льненого пок зник ефективності. ле порівняльний н ліз з стосовується, як пр вило, при вирішенні т ких 3 д ч, як [1]: вибір н йкр щого об'єКт серед льтерн тивних в рі нтів, визн чення місця цього об'єкт серед н логів, визн чення групи кр щих льтерн тивних в рі нтів, розподіл льтерн тивних в рі нтів н упорядков ні групи (н прикл д, групи «кр щих», «середніх» т «гірших» об 'єктів). ому, вр ховуючи неоднозн чність опису процесу використ ння у перспективі (через 10-15 років), природно припустити, що обгрунтув ння до перспективних зр зків пов'яз но с ме 3 прогнозув нням, не з порівняльним н лізом вже існуючих зр зків.

ким чином, існуючі н уково-методичні підходи щодо обгрунтув ння до перспективних зр зків не дозволяють в суч сни х умов $\mathrm{x}$ дост тньо вр хув ти невизн ченість вихідних д них т неоднозн чність опису процесу використ ння перспективних зр зків

р хув ти з зн чені особливості 3 вд ння обгрунтув ння до перспективних зр зків дозволяє м тем тичний п р т, який г рунтується н теорії нечітких множин.

ет ст тті. т ттю підготовлено 3 метою обгрунтув ння підходу щодо формув ння кількісних

$$
\text { до перспективних зр зків }
$$

використ нням поняття нечіткої множини.

\section{сновний м тері л}

чевидно, що основними ф ктор ми, які визн ч ють технічний обрис і вимоги до , є перелік з вд нь т місце їх викон ння в опер тивно т ктичній побудові військ. 3 лежності від цих ф кторів н поч тковому ет пі для кожного зр зк

здійснюється вибір основних п р метрів (пок зників), які з безпечують н йбільш ефективне його з стосув ння і є вихідними для визн чення інших.

н ступному ет пі з метою отрим ння оцінок основних п р метрів перспективних зр зків проводиться експертне опитув ння. еред процедур експертного опитув ння, які дозволяють отрим ти прогнозні оцінки т м ють, у порівнянні з іншими, менше недоліків, можн використ ти послідовну ітер тивну процедуру, докл дно опис ну в [9]. Я процедур грунтується н почерговому включенні в опитув ння все більшої кількості експерті в ж до ст біліз ції їхніх оцінок.

р диційні підходи обробки кількісної експертної інформ ції (ст тистичний, лгебр їчний) м ють суттєві недоліки. пр в в тому, що експерт здійснює оцінку інтуїтивно, неявним способом i грунтується н всіх зн ннях, отрим них р ніше. його уявленні відповіддю н пит ння не обов' язково повинно бути точне число, ле т кож їм може бути деяк нечітк підмножин чисел $F$ обл сті міркув нь $U$, як $є$ підмножиною дійсної осі. ост нньому вип дку, якщо експерт д є оцінку як точну, т о це озн ч є, що він с м обир є єдиний елемент $U$, який, н його думку, м є н йбільший ступінь н лежності $F$, , крім того, ігноруються інші елементи $U$, хоч їх ступінь н лежності може бути близьким до 1 [10].

ому в $\mathrm{p}$ мк $\mathrm{x}$ з пропонов ного підходу форм ліз цію отрим них нечітких експертних оцінок п р метрів перспективних зр зків пропонується здійснити з використ нням нечітких множин і використовув ти приблизно точкові т приблизно інтерв льні оцінки. і оцінки можуть бути, н прикл д, т кими:

«Д льність польоту сн ряд приблизно повинн дорівнюв ти 30 км»;

«приблизно 3 5-10 хв. зр зок озброєння повинен переміститись н відст нь 3-4 км»;

«м с озброєння збільшиться т буде приблизно 6,2-6,5 т».

бробк експертних оцінок із використ нням теорії нечітких множин можлив тільки при з д них функціях н лежності, які відповід ють ост ннім. ля побудови функцій н лежності нечітких множин доцільно використ ти метод [10], який, н відміну від інших, дозволяє обробляти приблизно точкові т інтерв льні оцінки, збільшує декв тність форми їх предст влення у порівнянні 3 існуючими тр диційними метод ми обробки експертних оцінок. метою визн чення компромісних (уз г льнених) оцінок пропонується викорис товув ти згорт ння н основі опер ції перетину нечітких множин. пер ції перетину нечітких множин відповід $є$ опер ція min, як викону ється 3 їх функціями н лежності

$$
\begin{aligned}
& \mu_{D}\left(x_{i}\right)=\min \mu_{i j}, \quad j=1, \ldots ., m \\
& D=u_{1} \cap u_{2} \cap \ldots \cap u_{m},
\end{aligned}
$$

де ${ }_{D}\left(x_{i}\right)$ - функція н лежності компромісної оцінки п р метр виду $x_{i} ; D-$ компромісн

() . . упріненко, . . олуб 
оцінк п р метр виду , як визн ч ється опер цією перетину функцій н лежності нечітких множин, побудов них н основі експертних оцінок; $m$ - кількість експертних оцінок.

ля визн чення чітких зн чень отрим них компромісних оцінок доцільно використ ти методи приведення до чіткості (деф зифік ціі), викл дені в робот х [11-12].

підст ві з пропонов ного підходу розглянемо прикл д обгрунтув ння м си озброєння.

рипустимо, що в результ ті проведення експертного опитув ння отрим ні екс пертні оцінки, н ведені в т блиці.

кспертні оцінки, отрим ні в результ ті
проведення експертного опитув ння

оцінк ми м с озброєння, використовуючи підхід, н ведений у [10], побудов ні функції н лежності нечітких множин (рис.).

основі опер ції перетину функцій н лежності нечітких множин 3 вир зом (1) визн чено компромісну оцінку м си озброєння (з штрихов н обл сть н рис.).

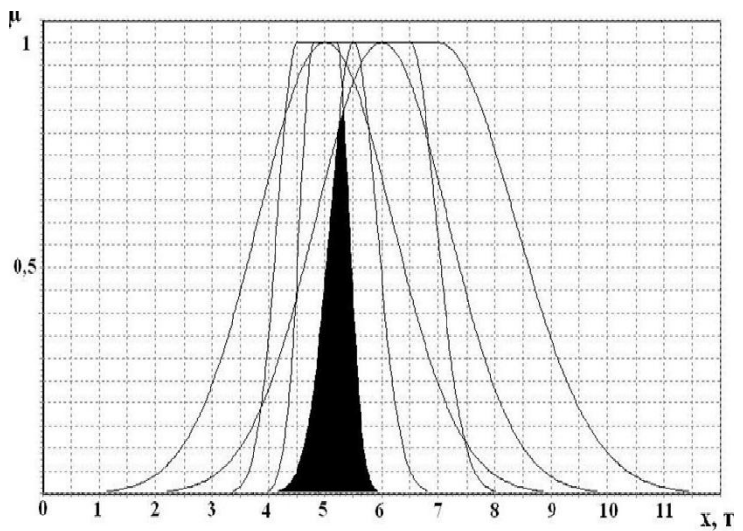

uc. ункції н лежності нечітких множин, побудо -

в них н основі експертних оцінок і компромісн

оцінк м си озброєння, визн чен опер цією перетину функцій н лежності нечітких множин

ітке зн чення отрим ної оцінки визн ч ємо, н прикл д, 3 критерієм м ксимуму (Max-Criterion) [11]. відповідності до цього методу чітке зн чення вибир ється серед множини елементів, в яких функція н лежності компромісної оцінки прийм $€$ м ксим льне зн чення.

цьому вип дку $\max \mu_{D}(x)=0,85, \quad$ бсцис цієї вершини (чітке зн чення отрим ної компромісної оцінки) дорівнює $5,33 \mathrm{~T}$.

\section{ИСНОВ К И}

ким чином, 3 пропонов ний підхід, н відміну від існуючих, вр ховує невизн ченість вихідних д них і неоднозн чність опису процесу використ ння перспективних зр зків і дозволяє обгрунтув ти т ктико-технічні вимоги до них в суч сних умов $\mathrm{x}$

\section{писок літер тури}

1. еменов . . иенк технического уровня обр зиов вооружения и военной техники / еменов . ., рчев . ., оффин . . - .. дио и связь, 2004. $552 \mathrm{c}$.

2. сновы прогр ммного метод пл ниров ния $p$ звития вооружения / [ . . олжин, . . узьмин, . . уб ренко, . . уев]. - .. оенное изд тельство, 1971. $-212 \mathrm{c}$.

3. уев .. ехнические 3 ди исследов ния опер ций / уев . ., пехов . . - .. оветское p дио, 1971. $-244 c$.

4. уев . . рогнозиров ние в военном деле / уев . ., их йлов . . - . : оенизд m, 1975. $279 \mathrm{c}$.

5. бр ботк нечеткой информ ции в систем $х$ принятия решений / [ . . орисов, . . лексеев, . еркурьев и др.]. - .. дио и связь, 1989. - 304 с.

6. дежность и эффективность в технике: спр вочник в $10 \mathrm{~m} . /[$ ед. . . вдуевского и др.]. - ..

шиностроение, $1987 . \quad$ - 9: ехническ я ди гностик. - 1987. -352 с.

7. ртыщенко . . етоды военно-н учных исследов ний в $в$ д ч $х$ р зр ботки и испыт ния вооружения / ртыщенко . ., нов . . - .. , 1981. - .1. $-1981 .-280 \mathrm{c}$.

8. руковский- иневич . . спользов ние принцип иде льного обр зи для обоснов ния т ктикотехнических требов ний $\kappa$ перспективным видм вооружения $u$ военной техники / руковскийиневич . ., олегенько . . // ртиллерийское и стрелковое вооружение. - 2005. - №3. - . 8-14.

9. нков . . рг низ ция экспертизы и н лиз экспертной информ иии / нков . ., етровский . ., нейдерм н . . - .. $\quad$ ук, 1984. -120 c.

10. кофенко . . построении функций прин длежности нечетких множеств, соответ ствующих количественным экспертным оиенкм/ кофенко . . // уковедение и информ тик . - иев: ук. думк , 1981. - ыл. 22. - .70-79.

11. руглов . . ечетк я логик и искусственные нейронные сети / руглов . ., ли . ., олунов . .$\therefore \quad$ 2001. $-224 c$

12. олуб . . етод деф зифік иії нечітких множин / олуб . ., упріненко . . // истеми обробки інформ ції. - 2007. - ип. 2 (60). - . 107-108.

дійшл до ред киї 21.11.2008

ецензент: доктор технічних н ук, ст рший н уковий співробітник . . орольов, ьвівський інститут ухо путних військ, ьвів. 


$$
\text { . . уприненко, . . олуб }
$$

роведен н лиз существующих н учно-методических подходов кобоснов нию т ктико-технических требов ний $\kappa$ перспективным обр зи, м вооружения и военной техники. ст новлено, что в современных условиях н н ч льных эт $n x p$ зр ботки они не позволяют дост точно учитыв ть неопределенность исход ных д нных и неоднозн чность опис ния процесс использов ния перспективных обр зиов вооружения и военной техники. редложен подход, основ нный н использов нии понятия нечеткого множеств, позволяющий обоснов ть т ктико-технические требов ния к перспективн ым обр зи, м вооружения и военной техники в современных условиях.

лючевые слов : $m$ ктико-технические требов ния, вооружение и военн я техник, нечеткое множество.

\title{
GROUND OF REQUIREMENTS TO THE PERSPECTIVE STANDARDS OF ARMAMENT AND MILITARY TECHNIQUE WITH THE USE OF FUZZY SET S
}

\author{
. N. Kuprinenko, V. . Golub
}

The analysis of the existent scientifically-methodical approaches is conducted to ground performance requirements to the perspective models of armament and military materiel. It is set that in modern term son initial design stages they do not allow to fully take into account the vagueness of basic data and ambiguousness of description of process of the use of perspective standards of armament and military materiel. Offered approach is based on the use of $c$ oncept of fuzzy set allowing to ground performance requirements to the perspective models of armament and military materiel in modern terms.

Keywords: performance requirements, armament and military materiel, fuzzy set.

\author{
$621.434(071)$ \\ . . остюк, . . усіло, . . ойко \\ ьвівський інститут ухопутних військ, ввів
}

ст тті розглянуто пит ння поперечної $m$ поздовжньо ї стійкості руху втомобіля $і$ методи ї̈ покр щення з допомогою вдоскон лених способів і системи регулюв ння тиску повітря в шин $x$.

лючеві слов : рмійський втомобіль, поздовжня $і$ поперечн стійкість, систем регулюв ння тиску повітря в шин $x$.

\section{ступ}

уч сний рмійський втомобіль - це скл дн 3 своєю конструкцією і т ктико-технічними х р ктеристик ми м шин .

н ліз теорії рмійського втомобіля т його основних елементів д є змогу оцінити пок зники експлу т ційних вл стивостей у конкретних умов $\mathrm{x}$ експлу т ції, т кож підібр ти необхідні технічні п р метри щодо його прохідності і м невреності [1].

ост новк проблеми. освід використ ння рмійських втомобілів у збройних конфлікт х висув є нові вимоги щодо удоскон лення їх конструкції, підвищення т кти ко-технічних x p ктеристик i експлу т ційних вл стивостей. еред них в жливими є стійкість і керов ність, які м ють визн ч льний вплив н ефективніс ть експлу т ції і безпеку руху.

н ліз ост нніх досліджень і публік цій. p ховуючи в жливість стійкості і керов ності втомобілів, ці пит ння вивч лися б г тьм дослідник ми. о теперішнього ч су розроблено теорію стійкості руху двовісних втомобілів [1-2] і розглянуто проблемні пит ння теорії стійкості б г товісних втомобілів [3-5]. проведених дослідженнях розкрив ється сутність фізичних явищ, які супроводжують втр ту стійкості і керов ності, що дозволяє конструктор м покр щити експлу т ційні вл стивості втомобіля ще н ст дії проектув ння.

ет ст тті. основі короткого н лізу експлу т ційних ф кторів і зовнішніх сил, які діють

(C) . . остюк, . . усіло, . . ойко 